\title{
Constipation in children: From misty to understanding
}

\author{
Shaman Rajindrajith ${ }^{1}$ \\ Sri Lanka Journal of Child Health, 2014; 43(3): 121-141
}

(Key words: Constipation in children; Sri Lanka)

President of the Sri Lanka College of Paediatricians (SLCP), Members of the Council of the SLCP, Fellows and Members of the SLCP, Members of the family of the late Dr. Stella de Silva, Distinguished Invitees. I count it a great honour and privilege to be afforded this opportunity to pay tribute to a most distinguished clinician, accomplished academic, acclaimed medical writer, editor par excellence and brilliant medical teacher who has contributed immensely to expansion and development of modern paediatrics in Sri Lanka. Her incredible life and the highest standards she set have been a source of inspiration and pride to those of us who have tried to follow in her footsteps and carry the torch which she lit and carried with great distinction for many a year as a pioneering clinician in this paradise emerald isle.

Stella Gertrude de Silva was born on $2^{\text {nd }}$ June, 1918. After finishing school, she entered Ceylon Medical College in 1937. She started her career as Consultant Paediatrician in 1954 at the Lady Ridgeway Hospital (LRH). This was the start of a legendary medical career as a Specialist and a kind hearted clinician serving masses of children in this country. She served in this country not only as a paediatrician but as a guide, teacher and sincere friend to the whole community. She served as a Consultant Paediatrician at LRH till her retirement in 1973 and provided the best possible care to young children suffering from curable and incurable maladies.

Her commitment to medical teaching is not secondary to any other in the same era and even in the years to follow. As a senior paediatrician at LRH, she has taught medical undergraduates and trained a number of distinguished young paediatricians. When the North Colombo Medical College started she was requested to set up the Department of Paediatrics in 1985 and became the Founder Professor of Paediatrics in that institution. Several legions of medical students benefitted from her vast experience

${ }^{1}$ Consultant Paediatrician and Senior Lecturer in Paediatrics, Department of Paediatrics, Faculty of Medicine. University of Kelaniya, Sri Lanka

in that endeavour. She had that glorious gift of being able to teach in a way that rationalized the entire practice of paediatrics. She continued to work in this position for quite a few years, training a multitude of undergraduate and postgraduate students.

Dr. Stella Gertrude de Silva is perhaps best described as "The Ultimate Paediatrician". I refer to her as the ultimate paediatrician with good reason. The term Paediatrics originates from the Greek word "Paedos" meaning a child, and "latros" implying a physician. The speciality is best described as the art and science of keeping children well and if and when they become sick, bringing them back to health as quickly as possible. When the illness becomes chronic and incurable, paediatricians should take adequate steps to minimize suffering. Dr. Stella de Silva is the epitome of all these and more. She followed this to the letter with one of the most meaningful medical adages in the back of her mind "to cure occasionally, relieve often and comfort always". She accomplished all this without fanfare and in a most humble manner. Children were her life and she gave of her very best to their welfare. An adoring "Godmother" to all those who came to her, she would leave no stone unturned in a relentless quest towards excellence in looking after them. She was indeed a shining beacon to follow for all of us who came after her.

In addition to caring for sick children and training the future generations of doctors, Dr. Stella excelled in scientific writing as well. Apart from her publications, she had been the cornerstone of the Sri Lanka Journal of Child Health. She was the editor of the Journal for 36 long years which itself is a record. Her legendary editing and extension of a helping hand to young struggling scientists to publish their scientific work have left an unmistakable footprint in scientific writings of Paediatrics in Sri Lanka. Dr. B J C Perera, my personal mentor, who delivered the Inaugural Dr. Stella de Silva Oration last year, portrayed her as a "Dazzling Star" and a "Priceless Legend". Ladies and Gentlemen, it is my remarkable dispensation now, to present my work in the field of 
Paediatrics, as a humble tribute and an accolade, to the memory of that very same "Dazzling Star".

\section{Introduction}

For thousands of years, bowel function has been considered a cornerstone in human health and deviation from the considered norm was perceived as detrimental to wellbeing. Human obsession on bowel habits has been everlasting. The first documented record on bowel habits is a $16^{\text {th }}$ century BC Egyptian pharmaceutical papyrus where ill health is explained as a process initiated by poisoning of the body by materials released from decomposing intestinal waste" $^{1}$. In 1856 Roots wrote "without daily bowel movements, the entire system will become deranged and corrupted. Diseased stomach, bad breath, rushes of blood to the head, bleeding at the lungs ..... are induced by neglect of this matter"' ${ }^{\prime 2}$ This theory has been widely believed by physicians even in the last century. It was stated that a person with constipation "is always working toward his own destruction; he made continual attempt at suicide by intoxication"3. This signifies the weight given to bowel function by human beings throughout the centuries. Early $19^{\text {th }}$ century, the laxative market started to thrive with the autointoxication theory as proponents stressed the need to clean the bowel on a regular basis to maintain health. Although this practice became obsolete around 1930 with the discard of the autointoxication theory and legislations to regulate marketing of laxatives, many still consider that regular bowel motions are imperative to sustain health and would seek medical advice with alteration of bowel habits.

Bowel habits may have received so much attention in the past because many defecation disorders, such as constipation and faecal incontinence, are very uncomfortable, long lasting, difficult to cure and likely to cause social embarrassment. Abnormal bowel habits and defecation disorders are commoner in children than in adults. Constipation in children has become a public health problem in some parts of the world. Prevalence of childhood constipation varies from $0.7 \%$ to $29 \%$ around the world ${ }^{4}$. Children with constipation are reported to visit medical clinics 7 times more than children with bronchial asthma and 3 times more than those with migraine headaches ${ }^{5,6}$. Furthermore, constipation claims staggering healthcare costs in adolescents ${ }^{7,8}$.

Childhood constipation has been a focus of research in developed countries during the last century and most information, currently available, has come from these countries. This led to the speculation that "Constipation is a disease of the western hemisphere". However, recent information from Asia suggests otherwise. A landmark study from Hong Kong has shown that one third of their kindergarten children have constipation ${ }^{9}$. A nationwide survey of Korean school children showed that $6.7 \%$ of them are having constipation ${ }^{10}$. Data from Japan and Iran show that $0.3-2.5 \%$ children have chronic constipation ${ }^{11,12}$. This data clearly shows shifting of epidemiological epicentre from the West to the East. From 2005 onwards we have been studying this interesting area in a series of researches. We made some discoveries and also helped expunge certain myths and improve the depth of understanding.

\section{PART 1: EPIDEMIOLOGY OF CONSTIPATION IN SRI LANKA}

This part is based on an epidemiological study of constipation of children in Sri Lanka using Rome III criteria $^{13}$. The aim was to study the prevalence and risk factors of constipation in Sri Lanka. It was a school-based, island-wide, cross-sectional survey. Three provinces were randomly selected and from them 5 schools were randomly selected. In each selected school, 12 classes were randomly selected from academic years 6 to 11 (2 from each academic year), and all children in the selected classes (ages 10-16 years) were included in the study. A pretested, validated questionnaire containing questions to identify demographic variables, bowel habits and associated symptoms was used for data collection. Constipation was diagnosed using Rome III criteria ${ }^{14}$. Of the 2694 children included in the analysis, 416 (15.4\%) had constipation and of them 230 (55.3\%) were males. We found a significant correlation between age and prevalence of constipation which has not been reported previously (Figure 1).

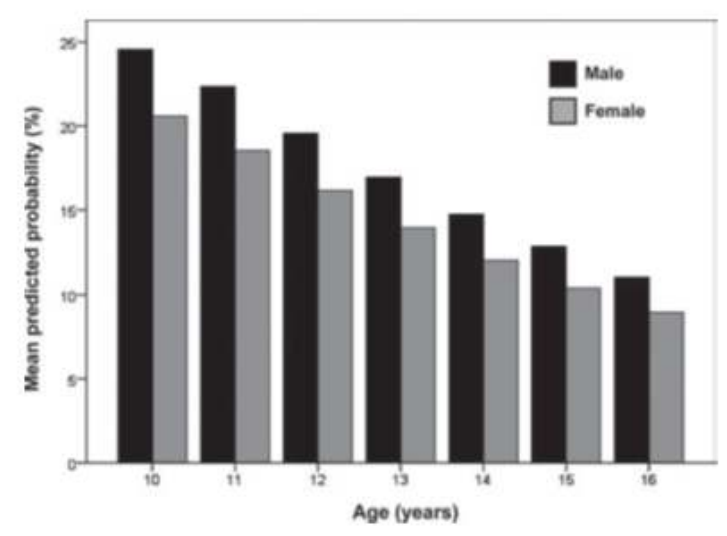

Figure 1: Mean predicted probability of constipation according to age and sex

After multivariate analysis, there was no significant gender difference in prevalence of constipation which is in agreement with other studies ${ }^{15,16}$. 
Table 1: Demographic and family characteristics of children with constipation

\begin{tabular}{|c|c|c|}
\hline Variable & $\begin{array}{c}\text { Distribution of responders } \\
\text { Number }(\%) \\
\end{array}$ & $\begin{array}{c}\text { Prevalence of constipation } \\
\text { Number }(\%) \\
\end{array}$ \\
\hline $\begin{array}{l}\text { Family size } \\
\text { Only child } \\
2-3 \text { children } \\
4 \text { or more children }\end{array}$ & $\begin{array}{c}214(07.9) \\
1955(72.6) \\
525(19.5)\end{array}$ & $\begin{array}{c}31(14.5) \\
295(15.1) \\
90(17.1)\end{array}$ \\
\hline $\begin{array}{l}\text { Birth order } \\
\text { Eldest } \\
\text { Youngest } \\
\text { Other }\end{array}$ & $\begin{array}{l}1018(41.1) \\
755(30.4) \\
707(28.5)\end{array}$ & $\begin{array}{l}151(14.8) \\
100(13.2) \\
134(19.0)\end{array}$ \\
\hline $\begin{array}{l}\text { Mother } \\
\text { Employed } \\
\text { Housewife }\end{array}$ & $\begin{array}{c}776(28.8) \\
1918(71.2)\end{array}$ & $\begin{array}{l}100(12.9) \\
316(16.5)\end{array}$ \\
\hline $\begin{array}{l}\text { Maternal employment } \\
\text { Leading profession (e.g. doctor, engineer) } \\
\text { Lesser Profession (e.g. nurse, teacher) } \\
\text { Skilled non manual (e.g. clerk) } \\
\text { Skilled manual } \\
\text { Unskilled/unemployed }\end{array}$ & $\begin{array}{c}40(01.5) \\
171(06.3) \\
88(03.3) \\
100(03.7) \\
2295(85.2)\end{array}$ & $\begin{array}{l}09(22.5) \\
23(13.4) \\
12(13.6) \\
20(20.0) \\
352(15.3)\end{array}$ \\
\hline $\begin{array}{l}\text { Father's social class } \\
\text { Leading profession } \\
\text { Lesser Profession } \\
\text { Skilled non manual } \\
\text { Skilled manual } \\
\text { Unskilled/unemployed }\end{array}$ & $\begin{array}{l}347(12.9) \\
202(07.5) \\
345(12.8) \\
964(35.8) \\
836(31.0)\end{array}$ & $\begin{array}{l}51(14.7) \\
23(11.4) \\
56(16.2) \\
143(14.8) \\
143(17.1)\end{array}$ \\
\hline $\begin{array}{l}\text { Location of school } \\
\text { Urban } \\
\text { Rural }\end{array}$ & $\begin{array}{c}1697(63.0) \\
997(37.0)\end{array}$ & $\begin{array}{c}283(16.7)^{*} \\
133(13.3)\end{array}$ \\
\hline $\begin{array}{l}\text { Living area } \\
\text { Eastern province (war affected areas) } \\
\text { Western province } \\
\text { Southern province }\end{array}$ & $\begin{array}{l}1078(40,0) \\
838(31.1) \\
778(28.9)\end{array}$ & $\begin{array}{c}195(18.1)^{* *} \\
123(14.7) \\
98(12.6)\end{array}$ \\
\hline $\begin{array}{l}\text { Family history of constipation } \\
\text { Positive } \\
\text { Negative }\end{array}$ & $\begin{array}{c}49(01.8) \\
2645(98.2)\end{array}$ & $\begin{array}{c}24(49.0)^{* * * *} \\
392(14.8)\end{array}$ \\
\hline
\end{tabular}

Table 1 demonstrates the association between demographic and family factors and constipation. Constipation was significantly higher in those with a history of constipation among first degree relatives and was significantly high in war affected areas. Terrorist activities and the war to liberate the Eastern province were going on during the time of the study. The stress related modulation of brain-gut axis is known to affect gut motility and bowel habits ${ }^{17}$ and probably plays a role in the aetiology of constipation. Furthermore, similar to previous studies ${ }^{18}$, prevalence of constipation was higher in children living in urban areas. High consumption of junk foods with low fiber content ${ }^{16}$ and living more sedentary life ${ }^{19}$ might have contributed to this. When we analysed bowel habits and symptoms in children with constipation, straining during defecation (adjusted OR 5.7, 95\% CI 4.4-7.9, $\mathrm{p}<0.0001$ ), blood in stools (adjusted OR $3.9895 \%$ CI 2.4-6.6, $\mathrm{p}<0.0001$ ) and abdominal pain (adjusted OR
$1.8,95 \%$ CI 1.4-0.2.3, $\mathrm{p}<0.0001$ ) were independently associated with constipation.

\section{PART 2: ASSOCIATIONS AND RISK FACTORS}

This part is based on a study of the association between constipation and stressful life events in a cohort of Sri Lankan children and adolescents ${ }^{20}$. Over $90 \%$ of children with constipation have no identifiable organic pathology for their symptoms and are considered to be having functional disorders. Psychological factors including emotional stress have long been considered a contributory factor for altered bowel habits in childhood constipation. According to previous studies, significant physical or psychological trauma, abnormalities in Child Behaviour Check List and history of personal health problems predispose children to develop constipation $^{25,26}$. Psychological stress is thought to 
influence gastrointestinal function through the braingut axis. These stress mediated changes in gastrointestinal functions have been well documented in some functional gastrointestinal diseases in children and adults such as functional abdominal pain and irritable bowel syndrome ${ }^{23,24}$. Up to now there were no systematic studies to assess the impact of day today stresses on bowel habits and defecation disorders. This study was conducted as a part of the epidemiological study to achieve this objective. In addition to the questions on constipation the questionnaire contained questions to assess home and school related stressful life events. In this study, 416 children with constipation identified during the previous study were compared with 2273 controls.

Patients with constipation had been exposed to significantly more stressful life events (mean 2.44, SD 2.28) than controls (mean 1.42, SD 1.69) $(\mathrm{p}<0.0001$, unpaired $\mathrm{t}$ test). Table 2 demonstrates the association between different stressful life events and constipation.

Table 2: Association between defecation disorders and exposure to stressful life events

\begin{tabular}{|c|c|c|c|}
\hline Stressful event & $\begin{array}{l}\text { Constipation } \\
\text { Number (\%) }\end{array}$ & $\begin{array}{c}\text { Faecal incontinence } \\
\text { Number }(\%)\end{array}$ & $\begin{array}{c}\text { Healthy controls } \\
\text { Number }(\%)\end{array}$ \\
\hline $\begin{array}{l}\text { Exposure to recent stressful life events } \\
\text { Yes } \\
\text { No }\end{array}$ & $\begin{array}{c}342(82.2)^{*} \\
74(17.8) \\
\end{array}$ & $\begin{array}{c}50(90.9)^{*} \\
05(09.1)\end{array}$ & $\begin{array}{l}1478(64.7) \\
805(35.3) \\
\end{array}$ \\
\hline $\begin{array}{l}\text { School related stressful events } \\
\text { Change in school } \\
\text { Suspension from school } \\
\text { Frequent punishment in school } \\
\text { Separation from best friend } \\
\text { Sitting for government exam } \\
\text { Failure in an examination } \\
\text { Being bullied at school }\end{array}$ & $\begin{array}{c}59(14.2)^{*} \\
04(01.0) \\
53(12.7)^{*} \\
133(32.0)^{*} \\
159(38.2) \\
82(19.7)^{*} \\
54(13.0)^{*}\end{array}$ & $\begin{array}{c}13(23.6)^{*} \\
02(03.6)^{*} \\
14(25.5)^{*} \\
18(32.7) \\
26(47.3) \\
15(27.2)^{*} \\
18(32.7)^{*}\end{array}$ & $\begin{array}{c}219(09.5) \\
07(0.3) \\
118(5.2) \\
519(22.2) \\
783(34.3) \\
244(10.7) \\
128(05.6) \\
\end{array}$ \\
\hline $\begin{array}{l}\text { Family related stressful events } \\
\text { Severe illness in a close family member } \\
\text { Death of a close family member } \\
\text { Loss of job by a parent } \\
\text { Divorce or separation of parents } \\
\text { Remarriage of a parent } \\
\text { Birth of a sibling } \\
\text { Frequent domestic fights } \\
\text { Frequent punishment by the parents } \\
\text { Father's alcoholism }\end{array}$ & $\begin{array}{c}106(25.5)^{*} \\
58(13.9)^{*} \\
30(07.2)^{*} \\
08(01.9) \\
08(01.9)^{*} \\
57(13.7)^{*} \\
20(04.8)^{*} \\
65(15.6)^{*} \\
31(07.4)^{*} \\
\end{array}$ & $\begin{array}{c}20(36.3)^{*} \\
08(14.5) \\
05(09.1)^{*} \\
03(05.5)^{*} \\
- \\
13(23.6)^{*} \\
07(12.7)^{*} \\
14(25.5)^{*} \\
07(12.7)^{*} \\
\end{array}$ & $\begin{array}{l}281(12.3) \\
179(07.8) \\
62(02.7) \\
21(0.9) \\
11(0.5) \\
162(07.1) \\
51(02.2) \\
140(06.1) \\
84(03.7) \\
\end{array}$ \\
\hline $\begin{array}{l}\text { Other } \\
\text { Hospitalisation of the child for other illness }\end{array}$ & $74(17.8)^{*}$ & $21(38.1)^{*}$ & $203(09.0)$ \\
\hline
\end{tabular}

$* p<0.001$ compared to healthy controls, Chi-squared test

After multiple logistic regression analysis, separation from the best friend (adjusted Odds ratio (OR) 1.35, $\mathrm{p}=0.017$ ), failure in an examination (adjusted OR 1.43, $\mathrm{p}=0.03$ ), severe illness in a family member (adjusted OR 1.64, $\mathrm{p}=0.001$ ), loss of job by a parent (adjusted OR $1.84 \mathrm{p}=0.016$ ), frequent punishment by parents (adjusted OR 1.77, $\mathrm{p}=0.003$ ) and living in a war affected area (adjusted OR 1.48, $\mathrm{p}=0.001$ ) remained to be independently associated with constipation.

The exact relationship between emotional stress and childhood functional constipation has not been assessed sufficiently. One study demonstrated an association between constipation and major physical or psychological trauma, history of personal health problems and abnormal oral habits ${ }^{21}$. Similar to our study Lisboa et al. noted that aggressiveness in the family in the form of punishment is associated with chronic constipation ${ }^{25}$. Our finding on association between examination failure at school and constipation was also confirmed by another study which showed association between difficulties at school and chronic constipation. Furthermore similar to our study both Inan et al. and Lisboa et al. did not find an association between constipation and divorce or separation of parents ${ }^{21,25}$. Association between defecation disorders and stress need a physiological explanation. It is possible that failure to cope with a stressful situation results in stress internalization which in turn leads to anxiety and other psychological distress. Slow colonic transit, an important pathophysiological factor in functional constipation, is associated with psychological symptoms such as anxiety and depression ${ }^{26,27}$. In addition, anxiety and psychological stress may 
contribute to the development of pelvic floor dyssynergia by increasing pelvic floor muscle tension $^{28}$. Stress may also act via the enteric nervous system to inhibit colonic motility and thus prolonged colonic transit ${ }^{29}$. These suggest a link between psychological stress, the central brain activity, enteric nervous systems and ano-rectal dysfunction.

\section{Impact of civil war on prevalence of constipation}

This part is based on a study of constipation in children during and after the civil war in Sri Lanka ${ }^{30}$. Relationship between civil war and constipation in children has not been studied in the past. According to an adult study, irritable bowel syndrome (IBS) was commoner in those exposed to civil war in Nicaragua $^{31}$. Another study found a higher prevalence of IBS in adults who were exposed to the Second World War as early as 6 to 18 months of age $^{32}$. We faced three decades of civil war with disruption of human life and social infrastructure. This would have resulted in a significant emotional stress for the school children living in these areas. Therefore, we hypothesized that constipation would be more common in children living in war affected areas. Proving our hypothesis, we found significantly more constipation among children living in war affected zone as shown in Table 1. Eastern province was liberated from terrorist groups in July 2007. Restoration of public facilities, resettlement of internally displaced people, and normalization of the civil life after the end of war is likely to reduce the emotional stress in the school children living in this area. Therefore we investigated the hypothesis that reduction in stress after the end of civil war reduces the prevalence of constipation of the children.

The first phase of the study was conducted during the civil war. During this period, there were events such as random checking of houses, bomb blasts and abduction and recruitment of children by separatist group as child soldiers and for other war related activities. Many schools were closed from time to time and children were forced to leave schools because of bomb threats. Public transport system in the war affected eastern province was constantly under the threat of landmines and claymore mines. Furthermore there were deliberate, pre-planned attacks against civilians living in the border villages of the Eastern province. The psychological trauma and stress generated by these events would probably have resulted in high prevalence of constipation observed in children living in war affected area during this period. Psychological stress is a key factor, which causes significant alterations in functions of the brain-gut axis ${ }^{17}$. In genetically and psychologically vulnerable individuals, this results in alterations of physiological functions of the lower gut, predisposing children to develop constipation.

Second phase was conducted from March to July 2009, two years after the end of the war and liberation of the Eastern province from separatist groups. By then, internally displaced personnel were resettled and most of the public facilities (e.g. roads, schools, hospitals etc.) were restored. The same questionnaire was distributed in similar settings to children aged 10-16 years in the same five schools included in phase I. During Phase II of the study 2164 children were recruited and 1173 (55\%) were males. Table 3 shows prevalence of constipation during and after the civil war in all provinces.

Table 3: Prevalence of constipation during \& after war

\begin{tabular}{|l|l|l|}
\hline \multicolumn{1}{|c|}{ Province } & $\begin{array}{c}\text { During war } \\
\text { No. (\%) }\end{array}$ & $\begin{array}{c}\text { After War } \\
\text { No. (\%) }\end{array}$ \\
\hline Eastern province $^{\mathrm{a}}$ & $195(18.1)$ & $71(10.0)^{\mathrm{b}}$ \\
\hline $\begin{array}{l}\text { Southern } \\
\text { province }\end{array}$ & $98(12.6)$ & $51(11.0)$ \\
\hline Western province & $123(14.2)$ & $67(12.1)$ \\
\hline
\end{tabular}

${ }^{a}$ War affected area; ${ }^{b} p<0.0001$

We have observed a significant reduction in prevalence of constipation two years after the end of war and liberation of this province from terrorist groups. Restoration of the day to day life after the end of the war would have reduced war related stressors in these children which would have contributed to the significant reduction observed in prevalence of constipation. Most of the other factors associated with constipation have remained constant during both phases. We have also demonstrated a higher predicted probability of constipation in war affected areas during phase I and a significant reduction in it after the war. So far, no other study has demonstrated a reduction in the prevalence of constipation after removal of stressful life events.

After multiple logistic regression analysis constipation was significantly higher among those living in war affected areas during phase I (adjusted OR 1.5, 95\% CI 1.1-1.9, $p=0.009)$. During phase II, prevalence of constipation has decreased in all three provinces (Eastern, Southern and Western) compared to phase I of the study. However, there was a statistically significant reduction in prevalence of constipation in previously war affected Eastern province compared to phase I $(p<0.0001)$. Figure 2 and Figure 3 show the mean predicted probabilities for constipation according to age groups. During the war (Phase I), mean predicted probabilities were significantly higher in all age groups in war affected 
Eastern province compared to other two provinces. Two years after the war (Phase II), mean predicted probabilities for constipation were lower in the Eastern province (Figure 3).

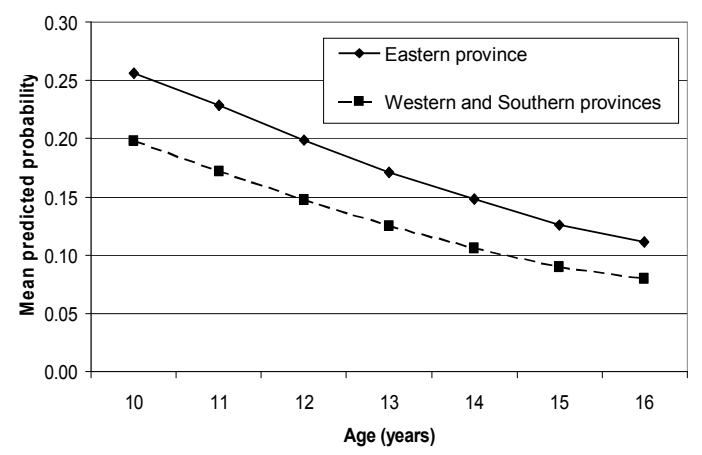

Figure 2: Mean predicted probabilities according to age groups during the war

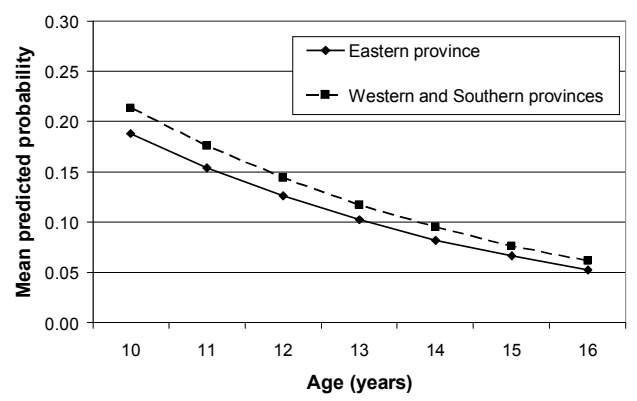

Figure 3: Mean predicted probabilities according to age groups after the war

\section{Association between child maltreatment and constipation}

This part of the study is based on a school based survey using Rome III criteria ${ }^{33}$. Child maltreatment is a major public health and social-welfare problem globally $^{34}$. It has deleterious effects on physical and mental health of victims throughout their lives. Maltreatment is defined as all forms of physical, sexual and emotional ill treatment and neglect that result in actual or potential harm to the child's health, development or dignity ${ }^{35}$. The, association between abuse and gastrointestinal illnesses in children have been studied only rarely. Studies in adults have shown that being abused as a child increases the vulnerability to develop functional gastrointestinal diseases (FGIDs) including functional dyspepsia and irritable bowel syndrome (IBS) ${ }^{36,37}$. These findings indicate long term repercussions of abuse on physiology of bodily function. However, all these studies in adults inquire about child abuse as a retrospective event. There is a clear dearth of evidence evaluating the association between child maltreatment and development of FGIDs in children. It had been shown that children who faced abuse develop post-traumatic stress disorders ${ }^{38}$. Somatisation is a common clinical issue in FGID patients. Adult studies have also clearly shown that abuse history was associated with more somatic symptoms ${ }^{39}$. Association between these factors has not been studied in children.

In this study we specifically aimed to assess any associations between history of child maltreatment and constipation in children and adolescents, the impact of child maltreatment on somatisation in children with constipation and the relationship between abuse and healthcare consultation in children with constipation.

This was a cross-sectional survey conducted in Gampaha District of Sri Lanka. Four schools of the district were randomly selected from 427 . From each school, all classes from grade 9 to 12 were chosen and children in these classes were invited to take part in the study. We used previously validated questionnaires for data collection:

1. Rome III questionnaire for functional gastrointestinal disease

2. Questionnaire on child maltreatment

3. Childhood somatisation inventory (CSI)

4. Symptom severity assessment

5. Healthcare consultation

Child abuse (physical, sexual and emotional) was defined using standard definitions ${ }^{40}$. We received 1855 completed questionnaires of which 1792 (96.7\%) were properly filled and were included in the analysis. Of them, $975(54.4 \%)$ were males [mean age 14.4 years, range 13-18 years, SD 1.3]. Constipation was noted in $138(7.7 \%)$ and was more prevalent among boys $(68.8 \%$ vs. $31.2 \%$ in girls, $\mathrm{p}<0.0001$ ). Children not meeting the Rome III criteria for constipation (1654) served as the control group. Four hundred and thirty eight (24.4\%) children were physically abused, $396(22.1 \%)$ were emotionally abused and 51 (2.8\%) were sexually abused. Compared with controls, children with constipation had a significantly higher prevalence of physical, sexual and emotional abuse (Table 4). 
Table 4: Constipation and child abuse

\begin{tabular}{|l|c|c|c|}
\hline \multicolumn{1}{|c|}{ Type of abuse } & $\begin{array}{c}\text { Children with constipation } \\
\text { No. (\%) }\end{array}$ & $\begin{array}{c}\text { Controls } \\
\text { No. (\%) }\end{array}$ & $\begin{array}{c}\text { p value } \\
\text { (Chi-square test) }\end{array}$ \\
\hline Physical abuse & $57(41.6)$ & $381(23.2)$ & $<0.0001$ \\
\hline Emotional abuse & $56(40.9)$ & $340(20.8)$ & $<0.0001$ \\
\hline Sexual abuse & $08(05.8)$ & $43(02.6)$ & 0.03 \\
\hline
\end{tabular}

Physical and emotional abuse were the strongest predictors of developing constipation $(p<0.0001)$. Child abuse is a problem worldwide. Exposure to abuse as a child has far reaching consequences such as psychological maladjustments, drug and alcohol misuse, risky sexual behaviour, obesity and criminal behaviour ${ }^{38}$. However, gastrointestinal consequences of child abuse have not been a research priority in the paediatric literature. In this study, we found that maltreatment is significantly associated with constipation in children. The association between patient perceived severity of bowel symptoms and abuse are given in Table 5.

Table 5: Patient perceived severity of bowel symptoms according to child abuse in children with constipation

\begin{tabular}{|l|c|c|c|}
\hline \multicolumn{1}{|c|}{ Type of abuse } & $\begin{array}{c}\text { Abused } \\
\text { Mean (SD) }\end{array}$ & $\begin{array}{c}\text { Not abused } \\
\text { Mean (SD) }\end{array}$ & $\begin{array}{c}\boldsymbol{p} \text { value } \\
\text { (Unpaired t-test) }\end{array}$ \\
\hline Physical abuse & $23.7(23.0)$ & $19.7(21.0)$ & 0.001 \\
\hline Emotional abuse & $25.4(22.6)$ & $19.3(21.1)$ & $<0.0001$ \\
\hline Sexual abuse & $26.4(21.6)$ & $20.6(21.5)$ & 0.05 \\
\hline
\end{tabular}

Constipated children with a history of physical and emotional abuse had more severe symptoms than children who were not exposed to abuse. This finding indicates the deleterious effects of abuse on not only developing constipation but also its significant contribution to severity of bowel symptoms.

Figure 4 shows mean somatisation scores of children who faced the 3 types of abuse.

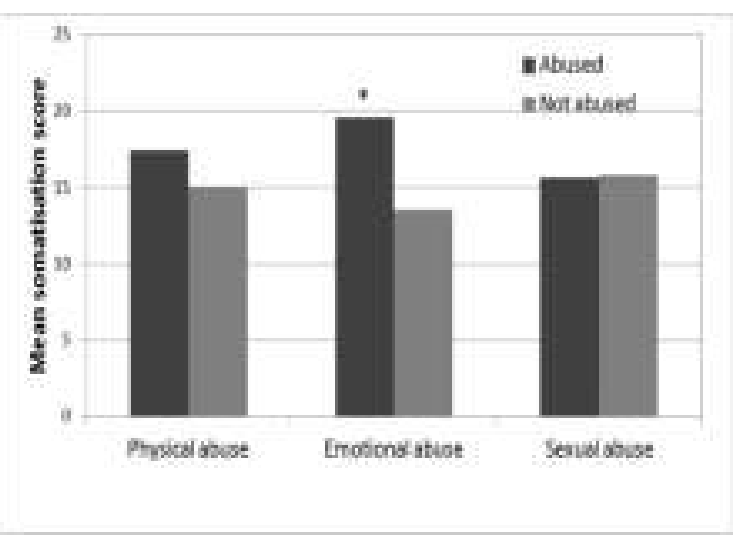

Figure 4 Association between child abuse and somatization score

Among children with constipation, the somatisation index was higher in those who experienced emotional abuse (19.8 vs. $13.5 \mathrm{p}=0.004)$. Somatisation index was higher in the total group of abused children with constipation (mean score 18.6, SD 12.5) compared to those without (mean score 13.9, SD 12.3) $(\mathrm{p}=0.03)$.
Somatic symptoms are an integral part of FGIDs in children and adults. Creed and co-workers found higher level of somatisation in adults with IBS when there was a history of sexual abuse in the past ${ }^{41}$. Our findings suggest development of adverse health effects of child abuse which is diverse and not limited only to psychological consequences. Exposure to abuse generates significant psychological stress both acutely and in the long term. Stress has a significant impact on the gastrointestinal tract. Animal studies have shown that exposure to stress predispose them to develop stress-induced visceral hypersensitivity ${ }^{42}$, altered defecation ${ }^{43}$, intestinal mucosal dysfunction ${ }^{44}$ and alterations in HPA axis ${ }^{45}$. The HPA axis has been implicated in the pathophysiology of post-traumatic stress disorders in children ${ }^{46,47}$. In general, traumatized children show significantly elevated cortisol levels compared with control groups. A study of children with post-traumatic disorders living in stable situations showed increased levels of 24-hour urinary cortisol in comparison to healthy controls ${ }^{48}$. In addition, several fMRI studies have also shown that abuse leads to activation of anterior mid cingulate and posterior cingulate cortex with deactivation in the anterior cingulated cortex supragenual region an area associated with downregulation of pain signals in adults with FGIDs including constipation ${ }^{39}$. These suggest that abuse leads to alteration of both hypothalamo-pituitaryadrenal axis and brain-gut axis that predispose individuals to develop FGIDs. Therefore, it is likely that in children exposed to stress induced by abuse, these pathophysiological mechanisms may play an 
important role in initiating and perpetuating symptoms of constipation.

\section{PART 3: EFFECTS OF CONSTIPATION ON LIVES OF CHILDREN}

This part is based on a school based study ${ }^{49}$. Health related quality of life (HRQoL) is a broad concept that incorporates the patient's perceptions, illness experience and functional status related to a medical condition $^{50}$. Assessment of HRQoL quantifies multiple factors producing patient's perception of illhealth, and is very valuable in diseases which do not have an objective biological marker to compute the impact of the disease on the affected individuals. Previous hospital based studies from tertiary care centres have shown that children with constipation have poor quality of life ${ }^{51,52}$. Furthermore, when childhood constipation continues into adulthood, it influences negatively on social contact and intimacy, in up to $20 \%$ of adults ${ }^{53}$. Despite these observations, there are no studies that formally address the physical, social and emotional impact of chronic constipation in children in the community. Studies among adults have shown that patients with functional gastrointestinal diseases have more somatic symptoms than healthy individuals ${ }^{54}$. Furthermore, patients with more somatic symptoms were known to seek medical advices for their gastrointestinal symptoms than controls ${ }^{54}$. Although somatisation is a known phenomenon in children, its association between constipation and HRQoL is unknown.

The main aims of this project were to a) study HRQoL in children/adolescents suffering from chronic constipation, b) study the somatic symptoms of chronic constipation and c) assess the effects of somatisation on HRQoL in school children. This part of the study was conducted as a part of the previous study. In addition, for this study we included a questionnaire to measure HRQoL in children. Out of 1855 completed questionnaires, 1792 (96.7\%) properly filled questionnaires were included in the final analysis. Of them, 975 (54.4\%) were males [mean age 14.4 years, range 13-18 years, SD 1.3]. Constipation was noted in $138(7.7 \%)$ children. Table 6 shows the mean HRQoL scores in children with constipation and controls.

Table 6: Health related quality of life scores for children with constipation and controls

\begin{tabular}{|l|lr|cc|c|}
\hline \multicolumn{1}{|c|}{ Quality of life domains } & \multicolumn{2}{|c|}{ Constipation $(\boldsymbol{n}=\mathbf{1 3 8})$} & \multicolumn{2}{c|}{ Controls $(\boldsymbol{n}=\mathbf{1 6 5 4})$} & \multicolumn{2}{c|}{$\boldsymbol{p}$ value } \\
& Mean & SD & Mean & SD & (Unpaired t-test) \\
\hline Physical functioning & 83.6 & 15.6 & 91.4 & 10.9 & $<0.0001$ \\
\hline Emotional functioning & 73.6 & 23.1 & 82.7 & 17.2 & $<0.0001$ \\
\hline Social functioning & 85.0 & 18.3 & 92.7 & 11.3 & $<0.0001$ \\
\hline School functioning & 75.0 & 20.6 & 82.5 & 16.6 & $<0.0001$ \\
\hline Overall quality of life score & 79.6 & 15.4 & 88.0 & 10.5 & $<0.0001$ \\
\hline
\end{tabular}

Children with constipation had lower HRQoL scores than controls in all 4 domains (physical, emotional, social and school functioning). Two previous studies have assessed the quality of life in children with chronic constipation using PedsQL questionnaire in tertiary care centres and reported similar results. Youssef and coworkers have assessed HRQoL in 80 children with chronic constipation and compared them with other chronic gastroenterological problems such as inflammatory bowel disease, gastroesophageal reflux and healthy controls. According to their results, the impact of constipation on quality of life of affected children is similar to that of inflammatory bowel disease ${ }^{55}$. These comparative results indicate severe ramifications of constipation on HRQoL in children. Figure 5 compares the mean HRQoL scores of children with constipation who had FI with those who do not have FI.

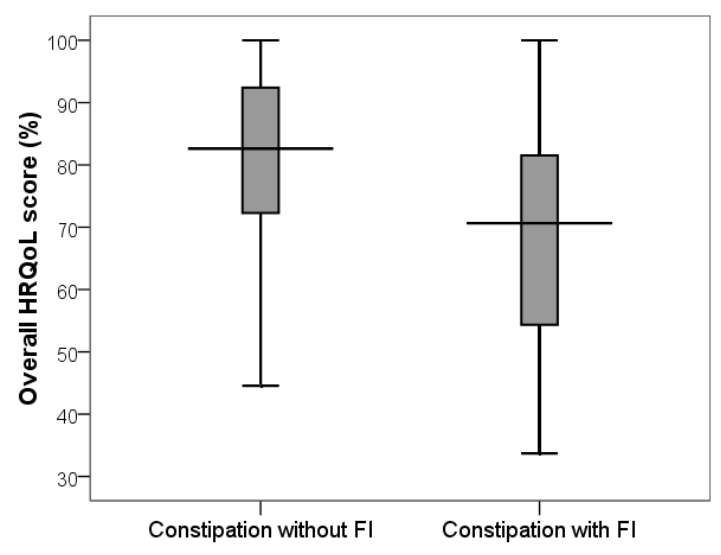

Figure 5: Comparison of overall HRQoL scores of children with constipation according to the presence of $\mathrm{FI}$ 
The data clearly indicate that children with constipation and FI have lower HRQoL than children with constipation alone $(p=0.02)$. FI or episodic leaking of faeces into the underwear is a troublesome symptom frequently associated with chronic constipation. This certainly causes social embarrassment, rejection by peers, and emotional problems in children ${ }^{56}$. It has also been shown that children with FI are vulnerable for bullying ${ }^{57,58}$.
Therefore, it is not surprising that the results of the current study show significantly lower HRQoL in children with constipation and FI compared to constipation alone. Table 7 compares all 24 items of the child somatisation inventory between children with constipation and controls.

Table 7: Somatisation scores for children with constipation and controls

\begin{tabular}{|c|c|c|c|c|c|}
\hline \multirow[t]{2}{*}{ Item } & \multicolumn{2}{|c|}{ Constipation $(n=138)$} & \multicolumn{2}{|c|}{ Controls $(n=1654)$} & \multirow{2}{*}{$\begin{array}{c}p \text { value } \\
\text { (Unpaired t-test) }\end{array}$} \\
\hline & Mean & SD & Mean & SD & \\
\hline Headache & 1.5 & 1.1 & 1.3 & 1.0 & 0.007 \\
\hline Faintness or dizziness & 0.5 & 0.8 & 0.4 & 0.7 & 0.01 \\
\hline Pain - heart or chest & 0.7 & 1.0 & 0.5 & 0.8 & 0.002 \\
\hline Low energy, slowed down & 1.0 & 1.2 & 0.5 & 0.9 & $<0.0001$ \\
\hline Pain - lower back & 0.9 & 1.3 & 0.5 & 0.9 & $<0.0001$ \\
\hline Sore muscles & 0.8 & 1.1 & 0.4 & 0.8 & $<0.0001$ \\
\hline Trouble getting breath & 0.7 & 1.2 & 0.3 & 0.7 & $<0.0001$ \\
\hline Hot or cold spells & 0.8 & 1.0 & 0.4 & 0.8 & $<0.0001$ \\
\hline Numbness or tingling & 0.9 & 1.1 & 0.5 & 0.8 & $<0.0001$ \\
\hline Weakness & 0.8 & 1.0 & 0.5 & 0.9 & $<0.0001$ \\
\hline Heavy feeling in arms, legs & 0.5 & 1.0 & 0.2 & 0.6 & $<0.0001$ \\
\hline Nausea, upset stomach & 0.8 & 1.0 & 0.3 & 0.7 & $<0.0001$ \\
\hline Constipation & 0.7 & 1.0 & 0.2 & 0.5 & $<0.0001$ \\
\hline Loose bowel movements, diarrhoea & 0.4 & 0.8 & 0.2 & 0.5 & $<0.0001$ \\
\hline Pain - stomach & 1.1 & 1.1 & 0.7 & 0.9 & $<0.0001$ \\
\hline Heart beating too fast & 0.7 & 1.0 & 0.3 & 0.7 & $<0.0001$ \\
\hline Difficulty in swallowing & 0.3 & 0.8 & 0.2 & 0.5 & 0.001 \\
\hline Losing voice & 0.4 & 0.9 & 0.2 & 0.6 & 0.001 \\
\hline Blurred vision & 0.6 & 1.0 & 0.3 & 0.7 & $<0.0001$ \\
\hline Vomiting, throwing up & 0.4 & 0.8 & 0.2 & 0.5 & $<0.0001$ \\
\hline Feeling bloated, gassy & 0.4 & 0.8 & 0.2 & 0.6 & $<0.0001$ \\
\hline
\end{tabular}

Except vomiting, scores obtained for all other somatic symptoms were higher in children with constipation. Table 8 shows the factors related to HRQoL in children with constipation.

Table 8: Factors related to Health related quality of life in children with constipation

\begin{tabular}{|l|c|c|}
\hline \multicolumn{1}{|c|}{ Factor } & Pearson correlation coefficient & $\boldsymbol{p}$ value \\
\hline Age & -0.12 & 0.15 \\
\hline Severity of abdominal pain/discomfort & -0.22 & 0.01 \\
\hline Frequency of abdominal pain/discomfort & -0.05 & 0.55 \\
\hline Severity of bowel symptoms & -0.22 & 0.01 \\
\hline Frequency of defecation & 0.08 & 0.61 \\
\hline Total somatisation score & -0.47 & $<0.0001$ \\
\hline
\end{tabular}

In our study, we found a significant negative correlation between HRQoL and scores obtained for somatisation index, severity of abdominal pain and bowel symptoms. Somatic symptoms such as aches, pains and altered bodily function have a significant impact on daily activities and hence on HRQoL. In addition, abdominal pain and bowel symptoms can be bothersome and contribute to escalation of suffering in constipated children.

PART 4: CLINICAL EVALUATION

This part is based on an invited book chapter ${ }^{59}$. Children with constipation could present to the clinician with a myriad of complaints some of which may be subtle and the attending paediatrician should 
be experienced enough to identify that the child may be having constipation. Furthermore, presenting complaints of constipation vary in different age groups. Some of the identified presenting features of constipation are given in Box 1 .

\section{Box 1: Presenting features of constipation}

Reduce defecation frequency
Pain/crying during passing stools
Faecal incontinence
Stool with holding manoeuvres
Occasional passage of large volume stool
Straining
Bleeding per rectum
Abdominal pain
Abdominal distension
Urinary incontinence
Refractory vulvovaginitis

Since constipation is a symptom based diagnosis, a thorough history not only confirms the diagnosis but helps to unravel possible underlying causes and complications. Discussing minutiae of bowel habits may be socially embarrassing to child as well as parents. Therefore, the paediatrician should make every attempt to alleviate embarrassment, listen attentively, ask relevant questions rather gently and assure the child as well as the family that their complaints are being taken seriously. It is imperative to build a good rapport with the family to extract all relevant information needed to ensure optimum care for the child. It is also vital to keep in mind that, parents and children interpret changes in bowel habits and symptoms of constipation in different ways and therefore, the paediatrician may have to guide them during history taking. In addition, assessing infants and toddlers is a challenge to the clinician. Many parents do not understand the normal, age related changes in bowel habits and often bring their young children for medical attention thinking that the baby has constipation. During the first 2 years of life, babies cannot effectively communicate their symptoms and the clinician has to entirely rely on information given by parents or guardian. In addition, young children are often frightened and interact poorly with the clinician due to anxiety. Basic components of the clinical history are given in Box 2 .

It is mandatory to perform a complete physical examination on children suspected of having constipation to confirm the diagnosis of constipation, identify severity of the disease, rule out possible underlying organic pathologies and to assess the severity.

\section{Box 2- Main components of clinical history}

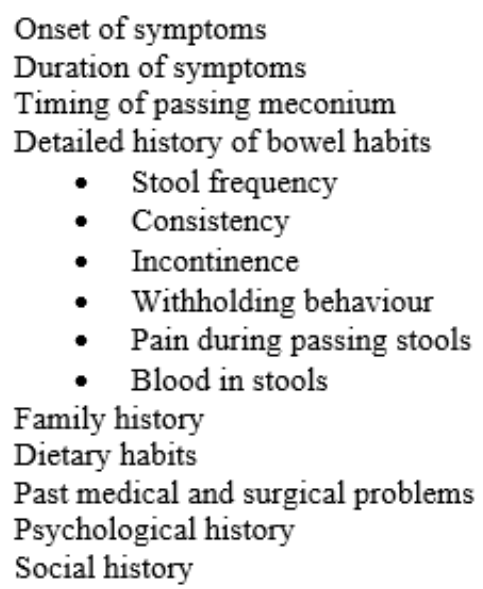

Physical examination should consist of a thorough general examination and comprehensive system examination including a careful abdominal (including perianal and rectal examination) and neurological assessment. Some children with constipation are extremely agitated and anxious during the examination, especially during perianal and rectal examination. Cooperation of the child can be gained by explaining the purpose of the examination and talking to the child throughout the procedure. Table 9 gives the main components of the physical examination.

Table 9: Components of the physical examination of children with constipation

\begin{tabular}{|l|l|}
\hline \multicolumn{1}{|c|}{ Section } & \multicolumn{1}{c|}{ Features } \\
\hline General examination & $\begin{array}{l}\text { Growth assessment } \\
\text { Dysmorphic features }\end{array}$ \\
\hline Abdominal examination & $\begin{array}{l}\text { Distension } \\
\text { Surgical scars } \\
\text { Palpable faecal masses }\end{array}$ \\
\hline Perianal examination & Anal position \\
& Dermatitis \\
& Scars \\
& Fissures \\
& Tags \\
& Patulous anus \\
& Sensory testing \\
\hline Digital examination & Tenderness \\
& Resting tone \\
& Squeeze pressure \\
& Nature and size of the \\
faecal mass \\
& Size of the rectum \\
\hline Lower limb neurology & Sensory \\
& Motor \\
\hline Development assessment & All 4 dimensions \\
\hline
\end{tabular}


At the end of a detailed history and a thorough physical examination, the clinician would have a complete clinical picture of the child's problem in terms of possible aetiology, potential risk factors, and complications. Presence of red flag features (Box 3) invariably demands further investigations in terms of ruling out possible organic pathologies. Other children who have functional constipation are directed to appropriate clinical management.

\section{Box 3: Red flag features of constipation}

History of delayed passage of meconium
Bilious vomiting
Bloody diarrhoea
Failure to thrive
Developmental delay
Abdominal distension
Ectopic anus
Perianal fistulae
Features of spina bifida
Asymmetric growth of lower limbs
Loss of perianal sensation
Abnormal neurological signs in lower limbs

\section{PART 5: MANAGEMENT OF CONSTIPATION}

This part is based on 2 review articles ${ }^{60,61}$, the Asian constipation guideline ${ }^{62}$ (where I was the only paediatrician) and an invited book chapter in the Paediatric Gastroenterology and Hepatology ${ }^{63}$. Constipation is a clinical diagnosis. Using currently accepted clinical criteria, the majority of children who present to a medical facility can be diagnosed and managed successfully. Specialised investigations are only needed when the diagnosis is uncertain or when they do not respond to standard management strategies. Investigations are also warranted in children who are suspected to have organic disorders leading to constipation during clinical evaluation.

\section{Investigations}

Radiological tests include colonic transit times, ultrasonography, endosonography, abdominal x-ray, and defecograpgy. Colonic transit time gives an idea of propulsive function of the colon and helps to identify segments with abnormal motility. It is measured using radio-opaque markers or scintigraphic methods. Several studies have shown abnormalities in total and segmental transit times in children with functional constipation using radioopaque markers ${ }^{64}$. A Dutch study noted children with functional constipation having colonic transit time over 62 hours. This cut-off value has a sensitivity of $52 \%$ and specificity of $91 \%{ }^{65}$. Colonic transit time also has an inverse relationship with the number of defecations per week ${ }^{64}$.

Using colonic scintigraphy, Sutcliffe et al. found delay in transit in patients with constipation ${ }^{66}$. Ultrasonography has also been used to assess the degree of faecal retention in the rectum. Using a trans-abdominal approach, several studies have measured the rectal diameter to determine faecal loading in the rectum using different methods and have shown that children with chronic constipation do have a larger rectal diameter compared to controls ${ }^{67}$. The results are promising and the wider availability and non-invasive nature of the test makes it an ideal investigation. However, methods need to be standardized and more studies are needed before recommending routine use of ultrasonography in assessing children with constipation. Using endosonography techniques, Keshtgar et al. have shown that children with chronic constipation have a thickened external anal sphincter complex ${ }^{68}$. The clinical utility value of this finding is yet to be determined. Plain abdominal $\mathrm{x}$-ray is used to demonstrate faecal loading in the colon and rectum. Several scoring systems are used to assess the degree of impaction. However, sensitivity and specificity of these tests are variable and also the inter-observer and intra-observer reliability are poor ${ }^{69}$. Therefore, the use of plain x-ray films of the abdomen as an investigation is not recommended. Other radiological investigations such as defecography and contrast enemas have no place in clinical evaluation of children with constipation. Magnetic resonance imaging of the spinal cord is an important investigation in children with refractory defecation disorders as some children have been shown to have significant abnormalities such as spina bifida occulta and terminal filum lipoma, especially when they have clinically detectable deviation of the gluteal cleft ${ }^{70}$.

Physiological tests: Ano-rectal manometry combined with balloon expulsion test is an important investigation to understand the function of the anorectal unit and pelvic floor muscles. It provides information about anal sphincter function, mechanisms of continence and defecation, rectal sensation, rectal compliance and ano-rectal reflexes ${ }^{71}$. Several studies have demonstrated multitude of abnormalities in ano-rectal function. They include increased rectal sensory threshold, reduced rectal contractility, high resting anal pressure and failure of relaxation of the external anal sphincter with rising rectal pressure ${ }^{72-73}$. Furthermore, a subset of children was found to have an abnormal balloon expulsion 
test $^{74}$. Colonic manometry allows the measurement of pressure/force from multiple regions within the colon in real time and helps to discriminate between normal colonic physiology and colonic myopathies and neuropathies ${ }^{75}$. A number of colonic motor patterns have been identified such as antegrade high amplitude propagating contractions, low amplitude propagating sequences, non-propagating contractions and retrograde propagating pressure waves ${ }^{76}$.

Other investigations: Association between cow milk protein (CMP) allergy and constipation is still debatable. Research has provided conflicting results $^{77-78}$. Therefore, testing for CMP allergy is not recommended. Importance of hypothyroidism as an aetiological factor for constipation in children is overstated. Bennett and Heuckeroth studied 56 children with hypothyroidism, and noted that only one child had constipation as the presenting complaint $^{79}$. Other serological tests such as screening for coeliac disease and hypercalcaemia are also not recommended as they rarely uncover diseases without supportive evidence from the history and physical examination.

\section{Management}

Effective management of constipation requires a multifaceted approach. A stepwise management protocol is shown in Figure 6.

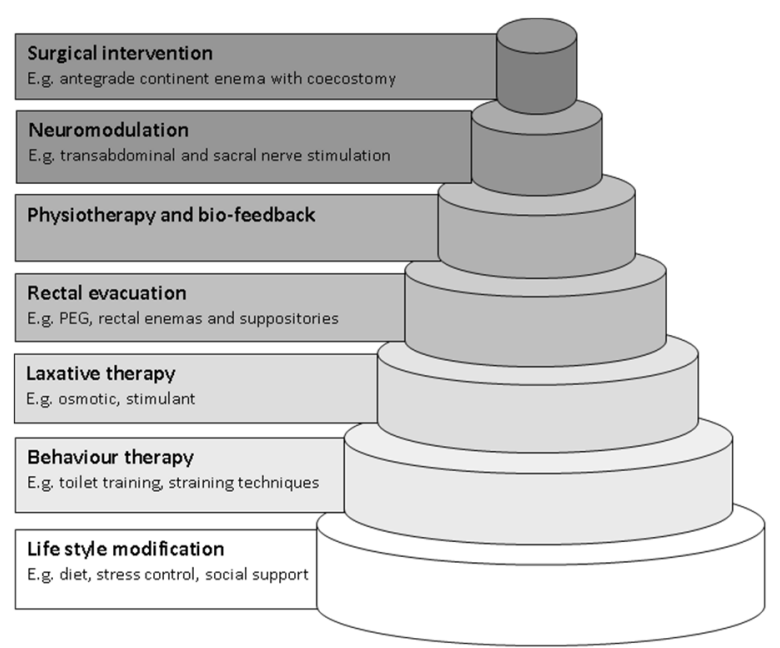

Figure 6: Management paradigm of constipation in children

The main steps include, life style modification, toilet training, use of laxatives and enemas, biofeedback therapy, nerve stimulation and surgical interventions. However, it is important to realise that the data in the paediatric literature to support evidence based use of treatment strategies are limited, especially regarding old laxatives such as lactulose and bisacodyl. Therefore, the management mostly depends on individual experiences and limited number of trials of new drugs.

Life style modifications: Constipation is known to be associated with psychological stress related to home, school and society ${ }^{20,30}$. These factors need to be addressed during the consultation. Children with psychological stress need to be identified and coping mechanisms need to be taught as part of the day-today lifestyle. Home and school related punishment is another factor that is known to predispose children to develop constipation which can easily be avoided ${ }^{33}$. Although widely believed, a high fibre diet does not relieve constipation. Several trials including different types of fibres failed to show any clinically meaningful therapeutic benefit in children ${ }^{80,81}$. Two systematic reviews also illustrate limited clinical value of fibre in the management ${ }^{82,83}$. In addition, increasing dietary fibre intake with extensive behavioural interventions does not reduce the requirement of laxatives ${ }^{84}$. Similarly, increase in consumption of water has also not been shown to increase stool frequency or soften stools ${ }^{85}$.

Toilet training and behavioural therapy: Stool withholding plays a crucial role in developing constipation in young children. Aiming to prevent this phenomenon, children with constipation need to re-learn to properly pass stools in the toilet. The child is encouraged to use the toilet regularly usually after each meal. The proper seating method (upright posture) and correct positioning of legs need to be taught. Once the child masters these techniques, it is necessary to teach him/her proper straining methods to facilitate the passage of stools. This process needs to be a regular practice and could be encouraged with a reward system ${ }^{86}$. A Cochrane review has shown positive evidence indicating that adding behavioural therapy to conventional laxatives has benefits in treating children with constipation ${ }^{87}$. It is obvious that behavioural therapy alone cannot cure constipation. However, given the importance of the part played by stool withholding behaviour in childhood constipation (especially in infants and younger children), toilet training and behavioural modifications are inseparable parts in day to day clinical management.

Faecal disimpaction from rectum: It had been shown that $40-100 \%$ of children with constipation have a large faecal mass in the rectum ${ }^{88}$. After evacuation of the faecal mass children are more likely to respond to maintenance therapy ${ }^{89}$. Several studies have proved 
that oral administration of polyethylene glycol (PEG) is both successful and cost-effective in the majority of children with faecal impaction ${ }^{90-92}$. Therefore, oral route is recommended as the initial step in rectal evacuation. Rectal enemas or suppositories are recommended for children who do not respond to oral drugs. A Dutch study failed to show a significant difference between PEG and rectal enemas on evacuation of rectum loaded with faeces ${ }^{92}$. However, it is imperative to realise the invasive nature of rectal therapy especially when the child has pain, discomfort. We recommend sedation before rectal administration of drugs. Rectal medications that are used include phosphate, docusate sodium, mineral oil enemas and bisacodyl suppositories. Once disimpaction is achieved, it is imperative that the clinician should concentrate on maintenance therapy. This facilitates passage of stools and prevents reimpaction.

Table 10 shows the details of the drugs that are currently used in the management of childhood constipation

Table 10: Dosages of most frequently used oral and rectal laxatives

\begin{tabular}{|c|c|}
\hline Drug class and Drug & Dosage \\
\hline $\begin{array}{l}\text { Osmotic laxatives } \\
\text { Lactulose, PEG } 3350 \\
\text { PEG } 4000 \\
\text { Milk of magnesia } \\
\text { (magnesium hydroxide) }\end{array}$ & $\begin{array}{l}1-2 \mathrm{gm} / \mathrm{kg} \text {, once or twice/day; maintenance: } 0.2-0.8 \mathrm{~g} / \mathrm{kg} / \text { day; fecal disimpaction: 1- } \\
1.5 \mathrm{~g} / \mathrm{kg} / \mathrm{day}(\text { with a maximum of } 6 \text { consecutive days) } \\
2-5 \mathrm{y}: 0.4-1.2 \mathrm{gm} / \text { day, once or divided; } 6-11 \mathrm{y}: 1.2-2.4 \mathrm{gm} / \mathrm{day} \text {, once or divided; } 12- \\
18 \mathrm{y}: 2.4-4.8 \mathrm{gm} / \text { day, once or divided }\end{array}$ \\
\hline $\begin{array}{l}\text { Faecal softeners } \\
\text { Mineral oil }\end{array}$ & $1-18$ y: $1-3 \mathrm{ml} / \mathrm{kg} /$ day, once or divided, $\max .90 \mathrm{ml} /$ day \\
\hline $\begin{array}{l}\text { Stimulant laxatives } \\
\text { Bisacodyl } \\
\text { Senna } \\
\text { Sodium picosulfate }\end{array}$ & $\begin{array}{l}3-10 \text { y: } 5 \mathrm{mg} / \text { day; }>10 \text { y: } 5-10 \mathrm{mg} / \text { day } \\
2-6 \text { y: } 2.5-5 \mathrm{mg} \text { once or twice/day; } 6-12 \mathrm{y}: 7.5-10 \mathrm{mg} / \text { day; }>12 \mathrm{y}: 15-20 \mathrm{mg} / \mathrm{day} \\
1 \mathrm{month}-4 \mathrm{y}: 2.5-10 \mathrm{mg} \text { once/day; } 4-18 \mathrm{y}: 2.5-20 \mathrm{mg} \text { once/day }\end{array}$ \\
\hline $\begin{array}{l}\text { Rectal laxatives/enemas } \\
\text { Bisacodyl } \\
\text { Sodium docusate } \\
\text { Sodium phosphate } \\
\text { Sodium Chloride } \\
\text { Mineral oil }\end{array}$ & $\begin{array}{l}2-10 \text { y: } 5 \mathrm{mg} \text { once } / \text { day; }>10 \mathrm{y}: 5-10 \mathrm{mg} \text { once } / \text { day } \\
<6 \text { y: } 60 \mathrm{ml} ;>6 \mathrm{y}: 120 \mathrm{ml} \\
1-18 \mathrm{y}: 2.5 \mathrm{ml} / \mathrm{kg}, \text { max. } 133 \mathrm{ml} / \mathrm{dose} \\
\text { neonate }<1 \mathrm{~kg}: 5 \mathrm{ml},>1 \mathrm{~kg}: 10 \mathrm{ml} ;>1 \mathrm{y}: 6 \mathrm{ml} / \mathrm{kg} \text { once or twice } / \text { day } \\
2-11 \text { y: } 30-60 \mathrm{ml} \text { once } / \text { day; }>11 \text { y: } 60-150 \mathrm{ml} \text { once } / \text { day }\end{array}$ \\
\hline
\end{tabular}

Osmotic laxatives: They are the group of choice used in the maintenance phase. As a group they exert an osmotic effect which helps to increase the water content in the colon and hence softening stools with minimal adverse effects. Lactulose and PEG are the two most commonly used drugs in this group. Although widely used, lactulose has never been compared with a placebo in a controlled trial. Perkin et al compared lactulose with senna using a small number of children. They noted a greater clinical response to senna (improving defecation frequency) when compared to lactulose $\mathrm{s}^{93}$. A recent randomized controlled trial using lactulose and a mixture of fibres showed that both therapeutic modalities are comparable without major side effects ${ }^{81}$. A Cochrane review has concluded the superiority of PEG over both placebo and lactulose ${ }^{94}$. However, it is important to realise that comparison of these studies is extremely difficult as the study designs, age groups and PEG preparations are different. PEG also shows an excellent safety profile. Therefore, in clinical practice, it is recommended to use both drugs as first line drugs in the maintenance phase.

Stimulant laxatives: Bisacodyl and senna stimulate peristaltic movements and enhance faecal evacuation. Studies comparing senna with lactulose and mineral oil demonstrated that children using senna had a poorer response $\mathrm{e}^{93}$. Another study comparing the effect of adding senna, placebo or no medication for children with faecal incontinence receiving behavioural therapy found no significant difference in outcome ${ }^{95}$. Despite the lack of well-designed trials these drugs are commonly used in day-to-day clinical practice, often in combination with osmotic laxatives. The National Institute for Clinical Excellence (NICE) guidelines of the United Kingdom recommend the addition of stimulant laxatives to PEG when the response is noted to be suboptimal ${ }^{96}$.

Biofeedback and physiotherapy: Ano-rectal function can be modified with the use of biofeedback. The purpose of biofeedback is to improve ano-rectal function and sensation ${ }^{61}$. Several studies have shown 
efficacy of biofeedback in correcting defecation dynamics, but a well conducted large randomized controlled trial failed to find additional clinical benefits of biofeedback in children with constipation $^{97,98}$. However, despite this finding it is vital to assess this therapeutic modality in combination with pelvic floor physiotherapy and muscle training as pelvic floor dys-synergia is a recognized physiological abnormality, especially in older children.

Neuromodulation: This has been identified as a successful therapeutic modality for elimination disorders ${ }^{97}$. Two trials have shown that sacral neuromodulation is effective in treating adults and children with slow transit or normal transit constipation $^{98,99}$. The adverse events were minimal. Trans-abdominal electrical stimulation has also been studied as an option for treatment of resistant slow transit constipation. Using this technique, two studies have illustrated children with slow transit constipation generating significantly higher frequency of high amplitude and total propagatory sequences and good clinical response with this therapy $^{100,101}$.

Surgical interventions: Injection of botulinum toxin (single or multiple) to the internal anal sphincter is effective in some children with dys-synergic defecation $^{102}$. Antegrade continent enema with appendicostomy or laparoscopic assisted percutaneous caecostomy has been used in treatment resistant constipation. It had been shown that the procedure improves bowel frequency and quality of life and reduces number of episodes of incontinence ${ }^{103}$. Commonly seen complications include granulation tissues around stoma, leakage, and minor infections. Major complications such as fistulae, peritonitis, and stenosis of the stoma are only seen in a minority ${ }^{104}$. Other surgical procedures such as sigmoid resection, colorectal resection, subtotal colectomy, and proctocolectomy with ileo-anal anastomosis are only reserved for children with intractable constipation who failed to respond to all other therapeutic modalities ${ }^{105}$.

\section{Summary}

We have shown that constipation is a significant health problem among school children in Sri Lanka affecting $15 \%$ of them. Compared to previous studies, prevalence of constipation is similar to that of western countries. In this study we noted that there is a clear negative correlation between the mean predicted probability of prevalence and age. It was shown that clinical features such as straining, blood in stools and abdominal pain are clearly associated with constipation. It was also established that living in war torn areas and urban areas and having a family history of constipation in a first degree relative predispose children to develop constipation. We found that home and school related stressful life events are significant driving forces for a child to develop constipation. Common home related events such as illness among family members, death of a family member, birth of a sibling, frequent domestic violence, punishment by parents, and alcohol abuse by father are clearly associated with developing childhood constipation. In addition, school related events such as changing school, punishments by teachers, failure of examination and being bullied at school also make children vulnerable to develop constipation. For the first time in the world we studied the association between constipation and child maltreatment. We have clearly demonstrated that violence against children in any form, physical, emotional or sexual, predisposes them to develop constipation. We also found that children with a history of physical and emotional abuse have more suffering (indicated by patient perceived severity of bowel symptoms) than children who do not have a history of abuse. This study also revealed that somatic symptoms are more common among children with constipation who have a history of abuse in any form. These novel findings indicate that child abuse has implications beyond its immediate traumatic experience and leads to deleterious repercussions on bowel functions and reactions in the brain-gut axis. By studying HRQoL of children with constipation we found that children with constipation have lower HRQoL scores for physical, emotional, social and school functioning. Furthermore, constipation associated faecal incontinence also leads to further reduction of HRQoL. In addition, patient perceived severity of bowel symptoms and abdominal pain and total somatization score negatively correlate with HRQoL scores, indicating consequences of untreated constipation on the lives of children. We have also shown that constipation is essentially a clinical diagnosis. A practicing clinician, with a detailed always is able to make a diagnosis of constipation and study its complications. Sophisticated investigations are only needed in children with unusual symptoms (red flags) and children who do not response to standard medical management. In the last section, we have developed a new paradigm for the management of childhood constipation. We reiterate that commonly used investigations such as X-rays, thyroid function tests and testing for abnormal calcium metabolism serves no purpose unless there are clinical evidence of such diseases. Physiological and radiological investigations are 
indicated only in a subset of children. In management we have shown that stepwise approach concentrating on life style modification, toilet training, oral and rectal medications can help the majority. Novel therapies such as pelvic floor physiotherapy, neuromodulation and innovative surgical approaches are reserved for children with severe symptoms despite optimal medical care. I believe this series of studies and reviews have expanded the horizon of understanding epidemiology, risk factors and effects of constipation in children. I also hope the aforementioned evaluation and management paradigms open a novel therapeutic window for caring children who are suffering from constipation.

\section{Acknowledgements}

I truly appreciate the guidance of Prof Harendra de Silva and Prof Janaka de Silva who guided me to do this wonderful subject of paediatric gastroenterology. I also wish to thank Prof Peter Sullivan, Head of the department of Paediatrics, University of Oxford for training me on looking after children with constipation. My most heartfelt gratitude goes to Prof. Marc A. Benninga, Head, Department of Paediatric Gastroenterology, Academic Medical Centre, Amsterdam, Netherlands for his continuous help, guidance and utmost friendship in conducting research in children with constipation. I am also extremely thankful to Dr. Niranga Devanarayana my wife and co-researcher for helping me conduct all this work. It would have been impossible to complete this work without her unconditional support throughout years of difficulty. Finally, I would like to acknowledge the continuous help I am getting from members of the Department of Paediatrics, University of Kelaniya and staff of ward 23, Teaching Hospital, Ragama.

\section{References}

1. Ebbell B, Banov L. The Papyrus Ebers: the greatest Egyptian medical document. Copenhagen: Levin and Munksgaard; 1937.

2. Roots HK. The People's Medical Lighthouse. New York: Ranney; 1856.

3. Bouchard $\mathrm{CH}$. Lectures on auto-intoxication in disease or self-poisoning of the individual. Philadelphia: Davis, 1906.

4. Mugie SM, Benninga MA, Di Lorenzo C. Epidemiology of constipation in children and adults: a systematic review. Best Practice
Research and Clinical Gastroenterology 2011; 25:3-18.

http://dx.doi.org/10.1016/j.bpg.2010.12.010

5. Ronmark E, Perzanowski M, Platts-Mills T, et al. Incidence rates and risk factors for asthma among school children: a 2-year follow-up report from the obstructive lung disease in Northern Sweden (OLIN) studies. Respiratory Medicine 2002; 96:1006-13. http://dx.doi.org/10.1053/rmed.2002.1391

6. Stang PE, Yanagihara PA, Swanson JW, et al. Incidence of migraine headache: a population-based study in Olmsted County, Minnesota. Neurology 1992; 42:1657-62. http://dx.doi.org/10.1212/WNL.42.9.1657

7. Liem O, Harman J, Benninga M, et al. Health utilization and cost impact of childhood constipation in the United States. Journal of Pediatrics 2009; 154:258-62.

http://dx.doi.org/10.1016/j.jpeds.2008.07.060

8. Choung RS, Shah ND, Chitkara D, et al. Direct medical costs of constipation in children older than 15 years: a population based birth cohort. Journal of Pediatric Gastroenterology and Nutrition 2011; 52(1): 47-54.

http://dx.doi.org/10.1097/MPG.0b013e3181e $\underline{67058}$

9. Ip KS, Lee WT, Chan JS, Young BW. A community-based study of the prevalence of constipation in young children and the role of dietary fiber. Hong Kong Medical Journal 2005; 11:431-6.

10. Chung JM, Lee SD, Kang DI, et al. An epidemiologic study of voiding and bowel habits in Korean children: a nationwide multicenter study. Urology 2010; 76:215-9. http://dx.doi.org/10.1016/j.urology.2009.12.0 $\underline{22}$

11. Sohrabi S, Nouraie M, Khademi H, et al. Epidemiology of uninvestigated gastrointestinal symptoms in adolescents: a population -based study applying the Rome III questionnaire. Journal of Pediatric Gastroenterology and Nutrition 2010; 51: 4145.

http://dx.doi.org/10.1097/MPG.0b013e3181d $\underline{1 \mathrm{~b} 23 \mathrm{e}}$ 
12. Sagawa T, Okamura S, Kakizaki $\mathrm{S}$ et al. Functional gastrointestinal disorders in adolescents and quality of school life. Journal of Gastroenterology and Hepatology 2013; 28:285-90.

http://dx.doi.org/10.1111/j.14401746.2012.07

257.x

13. Rajindrajith S, Devanarayana NM, Adhikari C, Pannala W, Benninga MA. Constipation in children: an epidemiological study in Sri Lanka using Rome III criteria. Archives of Diseases in Childhood 2012; 97:43-5. http://dx.doi.org/10.1136/adc.2009.173716

14. Rasquin-Weber A, Hyman PE, Cucchiara S, et al. Childhood functional gastrointestinal disorders. Gut 1999; 45(suppl. II):II60-II68. http://dx.doi.org/10.1136/gut.45.2008.ii60

15. Uguralp S, Karaoglu L, Karaman A, et al. Frequency of enuresis, constipation and enuresis associated with constipation in a group of school children aged 5-9 years in Malatya, Turkey. Turkish Journal of Medical Science 2003; 33:315-20.

16. Roma-Giannikou E, Adamidis D, Gianniou $\mathrm{M}$, et al. Epidemiology of chronic constipation in Greek children. Hell Journal of Gastroenterology 1999; 12:58-62.

17. Kellow JE, Azpiroz F, Delvaux M, et al. Applied principles of neurogastroenterology: physiology/motility sensation.

Gastroenterology 2006; 130:1412-20.

http://dx.doi.org/10.1053/j.gastro.2005.08.061

18. Ludvigsson JF; Abis study group. Epidemiologycal study of constipation and other gastrointestinal symptoms in 8000 children. Acta Pediatrica 2006; 95:573-80. http://dx.doi.org/10.1080/08035250500452621

19. Sandler RS, Jordan MC, Shelton BJ. Demographic and dietary determinants of constipation in the US population. American Journal of Public Health 1990; 80:185-9. http://dx.doi.org/10.2105/AJPH.80.2.185

20. Devanarayana NM, Rajindrajith S. Association between constipation and stressful life events in a cohort of Sri Lankan children and adolescents. Journal of Tropical Pediatrics 2010; 56:144-8. http://dx.doi.org/10.1093/tropej/fmp077
21. Inan M, Aydiner CY, Tokuc B, et al. Factors associated with childhood constipation. Journal of Pediatrics and Child Health 2007; 43:700-6.

http://dx.doi.org/10.1111/j.14401754.2007.01 $\underline{165 . x}$

22. Benninga MA, Voskuijl WP, Akkerhuis GW, et al. Colonic transit times and behavioural profiles in children with defecation disorders. Archives of Disease in Childhood 1994; 89:13-16.

23. Devanarayana NM, de Silva DGH, de Silva HJ. Recurrent abdominal pain in a cohort of Sri Lankan children and adolescents. Journal of Tropical Pediatrics 2008; 54:178-83. http://dx.doi.org/10.1093/tropej/fmm114

24. Bennett EJ, Piesse $C$, Palmer $K$, et al. Functional gastrointestinal disorders: psychological, social and somatic features. Gut 1998; 42:414-20. http://dx.doi.org/10.1136/gut.42.3.414

25. Lisboa VCA, Felizola MCM, Martins LAN, et al. Aggressiveness and hostility in the family environment and chronic constipation in children. Digestive Diseases and Sciences 2008; 53:2458-63. http://dx.doi.org/10.1007/s10620-008-0230-1

26. Towers AL, Burgio KL, Locher JL, et al. Constipation in the elderly. Influence of dietary, psychological, and physiological factors. Journal of the American Geriatric Society $1994 ;$ 42:701-6.

27. Merkel IS, Locher J, Burgio $\mathrm{K}$, et al. Physiologic and psychologic characteristics of an elderly population with chronic constipation. American Journal of Gastroenterology 1993; 88:1854-9.

28. Whitehead WE, Wald A, Diamant NE, et al. Functional disorders of the anus and rectum. Gut 1999; 45(Suppl. II): II55-9. http://dx.doi.org/10.1136/gut.45.2008.ii55

29. Chan AOO, Cheng C, Hui WM, et al. Differing coping mechanisms, stress level and ano-rectal physiology in patients with functional constipation. World Journal of Gastroenterology 2005; 11:5362-6. 
30. Rajindrajith S, Mettananda S, Devanarayana NM. Constipation during and after the civil war in Sri Lanka: a paediatric study. Journal of Tropical Pediatrics 2011; 57:439-43. http://dx.doi.org/10.1093/tropej/fmr013

31. Wurzelmann D, Pena R, Cortes L, et al. Positive association between traumatic war experience in the Sandinista revolution and subsequent IBS: a population-based study in Nicaragua (Abstract). Gastroenterology 2008; 134(4 Suppl. 1):A112. http://dx.doi.org/10.1016/S00165085(08)605 $\underline{24-7}$

32. Klooker TK, Braak B, Painter RC, et al. Exposure to severe wartime conditions in early life is associated with an increased risk of irritable bowel syndrome: a population based cohort study. American Journal of Gastroenterology 2009; 104:2250-6. http://dx.doi.org/10.1038/ajg.2009.282

33. Rajindrajith S, Devanarayana NM. Lakmini C, Subasinghe V, de Silva DG, Benninga MA. Association between child maltreatment and constipation: a school based survey using Rome III criteria. Journal of Pediatric Gastroenterology and Nutrition 2014; 58:486-90.

http://dx.doi.org/10.1097/MPG.00000000000 $\underline{00249}$

34. Gilbert R, Widom CS, Browne $\mathrm{K}$, et al. Burden and consequences of child maltreatment in high-income countries. Lancet 2009; 373:68-81. http://dx.doi.org/10.1016/S01406736(08)617 $\underline{06-7}$

35. Lebb RT, Paulozzi LJ, Melanson C, et al. Child maltreatment surveillance. Uniform definitions for public health and recommended data elements. Atlanta: Centers for Disease Control and Prevention, 2008.

36. Koloski NA, Talley NJ, Boyce PM. A history of abuse in community subjects with irritable bowel syndrome and functional dyspepsia. Digestion 2005; 72:86-96. http://dx.doi.org/10.1159/000087722

37. Talley NJ, Fett SL, Zinsmeister AR. Selfreported abuse and gastrointestinal disease in outpatients: association with irritable bowel type symptoms. American Journal of Gastroenterology 1995; 90:366-71.

38. Widom CS. Posttraumatic stress disorder in abused and neglected children grown up. American Journal of Psychiatry 1999; 156:1223-9.

39. Drossman DA. Abuse, trauma and GI illness: is there a link? American Journal of Gastroenterology 2011; 106:14-25. http://dx.doi.org/10.1038/ajg.2010.453

40. Butchart A, Harvey AP. Preventing child maltreatment: a guide to taking action and generating evidence. Geneva: World Health Organization 2006; 7-10.

41. Creed F, Tomenson B, Guthrie E, et al. The relationship between somatisation and outcome in patients with severe irritable bowel syndrome. Journal of Psychosomatic Research 2008; 64:613-20.

http://dx.doi.org/10.1016/j.jpsychores.2008.0 $\underline{2.016}$

42. Coutinho SV, Plotsky PM, Sablad M, et al. Neonatal maternal separation alters stressinduced responses to viscerosomatic nociceptive stimuli in rat. American Journal of Physiology, Gastrointestinal and Liver Physiology 2002; 282:G307-G316.

43. Gareau MG, Jury J, Yang PC, et al. Neonatal maternal separation causes colonic dysfunction in rat pups including impaired host resistance. Pediatric Research 2006; 59:83-8. http://dx.doi.org/10.1203/01.pdr.0000190577. $\underline{62426.45}$

44. Gareau MG, Jury J, Perdue MH. Neonatal maternal separation of rat pups results in abnormal cholinergic regulation of epithelial permeability. American Journal of Physiology, Gastrointestinal and Liver Physiology 2007; 293:G198-203. http://dx.doi.org/10.1152/ajpgi.00392.2006

45. Ladd CO, Owens MJ, Nemeroff CB. Persistent changes in corticotropin-releasing factor neuronal systems induced by maternal deprivation. Endocrinology 1996; 137: 1212 8 . 
46. Carlson M, Earls F. Psychological and neuroendocrinological sequelae of early social deprivation in institutionalized children in Romania. Annals of New York Academy of Science 1997; 807:419-28.

http://dx.doi.org/10.1111/j.17496632.1997.tb 51936.x

47. Carrion V, Weems C, Ray R, et al. Diurnal salivary cortisol in paediatric posttraumatic stress disorder. Biological Psychiatry 2002; 51:575-82. http://dx.doi.org/10.1016/S00063223(01)013 $\underline{10-5}$

48. DeBellis MD, Baum AS, Birmaher B, et al. Developmental traumatology. Part I: Biological stress symptoms. Biological Psychiatry 1999; 45:1235-6.

49. Rajindrajith S, Devanarayana NM, Weerasooriya L, Hathagoda W, Benninga NM. Quality of life and somatic symptoms in children with constipation: a school based study. Journal of Pediatrics 2013; 163:106972 .

http://dx.doi.org/10.1016/j.jpeds.2013.05.012

50. Wong RKM, Drossman DA. Quality of life measures in irritable bowel syndrome. Expert Review of Gastroenterology and Hepatology 2010; 4:277-84.

http://dx.doi.org/10.1586/egh.10.19

51. Feleiros FT, Machado NC. Assessment of health-related quality of life in children with functional defecation disorders. Journal of Pediatrics (Rio J) 2006; 82:421-5. http://dx.doi.org/10.2223/JPED.1530

52. Youssef NN, Langseder AL, Verga BJ, et al. Chronic childhood constipation is associated with impaired quality of life: a case controlled study. Journal of Pediatric Gastroenterology and Nutrition 2005; 41:5660.

http://dx.doi.org/10.1097/01.mpg.000016750 $0.34236 .6 \mathrm{a}$

53. Bongers ME, Benninga MA, Maurice$\mathrm{StamH}$, et al. Health related quality of life in young adults with symptoms of constipation continuing from childhood into adulthood. Health and Quality of Life Outcomes 2009; 7:20.

http://dx.doi.org/10.1186/1477-7525-7-20
54. Singh P, Agnihotri A, Pathak MK, et al. Psychiatric, somatic and other functional gastrointestinal disorders in patients with irritable bowel syndrome at a tertiary care center. Journal of Neurogastroenterology and Motility 2012; 18:324-31. http://dx.doi.org/10.5056/jnm.2012.18.3.324

55. Youssef NN, Langseder AL, Verga BJ, et al. Chronic childhood constipation is associated with impaired quality of life: a case controlled study. Journal of Pediatric Gastroenterology and Nutrition 2005; 41:5660.

http://dx.doi.org/10.1097/01.mpg.000016750 $\underline{0.34236 .6 \mathrm{a}}$

56. van der Wal MF, Benninga MA, Hirasing RA. The prevalence of encopresis in multicultural population. Journal of Pediatric Gastroenterology and Nutrition 2005; 40: 345-8.

http://dx.doi.org/10.1097/01.MPG.00001499 $\underline{64.77418 .27}$

57. Joinson C, Heron J, Butler U, et al. Psychological difference between children with and without soiling problems. Pediatrics 2006; 117:1575-84.

http://dx.doi.org/10.1542/peds.2005-1773

58. Bongers ME, van Dijk M, Benninga MA, et al. Health related quality of life in children with constipation-associated fecal incontinence. Journal of Pediatrics 2009; 154:749-53.

http://dx.doi.org/10.1016/j.jpeds.2008.11.029

59. Rajindrajith S, Devanarayana NM. Clinical evaluation of children with constipation: History and physical examination. In: Ramon NN, Fabbro MA, editors. Constipation in children. Chapter 6. Nova Publishers. 2013.

60. Rajindrajith S, Devanarayana NM. Constipation in children: diagnosis and management. Sri Lanka Journal of Child Health, 2009; 38: 127-35. http://dx.doi.org/10.4038/sljch.v38i4.1392

61. Constipation in children: Novel insight into epidemiology, pathophysiology and management Rajindrajith S, Devanarayana 
NM. Journal of Neurogastroenterology and Motility 2011; 17:35-47.

http://dx.doi.org/10.5056/jnm.2011.17.1.35

62. Gwee KA, Ghoshal UC, Gonlachanvit S, Chua AS, Myung SJ, Rajindrajith S. Primary care management of chronic constipation in Asia: The ANMA chronic constipation tool. Journal of Neurogastroenterology and Motility 2013; 19:149-60.

http://dx.doi.org/10.5056/jnm.2013.19.2.149

63. Rajindrajith S, Devanarayana NM, Benninga MA. Defecation disorders in children: Invited book chapter. In Guwandalini S, Barr P, Dhawan A, Editors. Pediatric Gastroenterology Hepatology, and Nutrition.

64. Gutierrez C, Marco A, Nogales A, et al. Total and segmental colonic transit time and anorectal manometry in children with chronic idiopathic constipation. Journal of Pediatric Gastroenterology and Nutrition 2002; 35:3138.

http://dx.doi.org/10.1097/0000517620020700 $\underline{0-00008}$

65. Benninga MA, Buller HA, Tytgat GN, et al. Colonic transit time in constipated children: does pediatric slow-transit constipation exist? Journal of Pediatric Gastroenterology and Nutrition 1996; 23:241-51.

http://dx.doi.org/10.1097/0000517619961000 0-00007

66. Sutcliffe JR, King SK, Hutson JM, et al. Gastrointestinal transit in children with chronic idiopathic constipation. Pediatric Surgery International 2009; 25:465-72. http://dx.doi.org/10.1007/s00383-009-2374-2

67. Bijos A, Czerwionka-Szaflarska M, Mazur A, et al. The usefulness of ultrasound examination of the bowel as a method of assessment of functional chronic constipation in children. Pediatric Radiology 2007; 37:1247-52.

http://dx.doi.org/10.1007/s00247-007-0659-y

68. Keshtgar AS, Ward HC, Clayden GS, Sanei A. Thickening of the internal anal sphincter in idiopathic constipation in children. Pediatric Surgery International 2004; 20:817-23.

http://dx.doi.org/10.1007/s00383-004-1233-4
69. de Lorijn F, van Rijn RR, Heijmans J, et al. The Leech method for diagnosing constipation: intra- and interobserver variability and accuracy. Pediatric Radiology 2006; 36:43-49.

http://dx.doi.org/10.1007/s00247-005-0031-z

70. Bekkali NL, Hagebeuk EE, Bongers ME, et al. Magnetic resonance imaging of the lumbosacral spine in children with chronic constipation or non-retentive fecal incontinence: a prospective study. Journal of Pediatrics 2010; 156:461-5.

http://dx.doi.org/10.1016/j.jpeds.2009.09.048

71. Belkind-Gerson J, Tran K, Di Lorenzo C. Novel techniques to study colonic motor function in children. Current Gastroenterology Reports 2013; 15:335. http://dx.doi.org/10.1007/s11894-013-0335-3

72. van den Berg MM, Voskuijl WP, Boeckxstaens GE, et al. Rectal compliance and rectal sensation in constipated adolescents, recovered adolescents and healthy volunteers. Gut 2008; 57:599-603. http://dx.doi.org/10.1136/gut.2007.125690

73. van der Plas RN, Benninga MA, Staalman $\mathrm{CR}$, et al. Megarectum in constipation. Archives of Disease in Childhood 2000; 83:52-58. http://dx.doi.org/10.1136/adc.83.1.52

74. Chitkara DK, Bredenoord AJ, Cremonini F, et al. The role of pelvic floor dysfunction and slow colonic transit in adolescents with refractory constipation. American Journal of Gastroenterology 2004; 99:1579-84. http://dx.doi.org/10.1111/j.15720241.2004.30 176.x

75. Dinning PG, Scott SM. Novel diagnostics and therapy of colonic motor disorders. Current Opinion in Pharmacology 2011; 11:624-9. http://dx.doi.org/10.1016/j.coph.2011.10.002

76. Dinning PG, Di Lorenzo C. Colonic dysmotility in constipation. Best Practice and Research Clinical Gastroenterology 2011; 25:89-101.

http://dx.doi.org/10.1016/j.bpg.2010.12.006

77. Iacono G, Cavataio F, Montalto $G$, et al. Intolerance of cow's milk and chronic 
constipation in children. New England Journal of Medicine 1998; 339:1100-4. http://dx.doi.org/10.1056/NEJM19981015339 1602

78. Irastorza I, Ibanez B, Delgado-Sanzonetti L, et al. Cow's-milk-free diet as a therapeutic option in childhood chronic constipation. Journal of Pediatric Gastroenterology and Nutrition 2010; 5:171-6.

http://dx.doi.org/10.1097/MPG.0b013e3181c $\underline{\mathrm{d} 2653}$

79. Bennett WE, Jr., Heuckeroth RO. Hypothyroidism is a rare cause of isolated constipation. Journal of Pediatric Gastroenterology and Nutrition 2012; 54: 285-7.

http://dx.doi.org/10.1097/MPG.0b013e31823 $\underline{9714 f}$

80. Castillejo G, Bullo M, Anguera A, et al. A controlled, randomized, double-blind trial to evaluate the effect of a supplement of cocoa husk that is rich in dietary fiber on colonic transit in constipated pediatric patients. Pediatrics 2006; 118:e641-648. http://dx.doi.org/10.1542/peds.2006-0090

81. Kokke FT, Scholtens PA, Alles MS, et al. A dietary fiber mixture versus lactulose in the treatment of childhood constipation: a double-blind randomized controlled trial. Journal of Pediatric Gastroenterology and Nutrition 2008; 47:592-7.

http://dx.doi.org/10.1097/MPG.0b013e31816 $\underline{2 c 43 c}$

82. Pijpers MA, Tabbers MM, Benninga MA, et al. Currently recommended treatments of childhood constipation are not evidence based: a systematic literature review on the effect of laxative treatment and dietary measures. Archives of Disease in Childhood 2009; 94:117-31.

http://dx.doi.org/10.1136/adc.2007.127233

83. Tabbers MM, Boluyt N, Berger MY, et al. Nonpharmacologic treatments for childhood constipation: systematic review. Pediatrics 2011; 128:753-61. http://dx.doi.org/10.1542/peds.2011-0179

84. Sullivan PB, Alder N, Shrestha B, et al. Effectiveness of using a behavioural intervention to improve dietary fibre intakes in children with constipation. Journal of
Human Nutrition and Dietetcs 2012; 25:3342.

http://dx.doi.org/10.1111/j.1365277X.2011.0 1179.x

85. Young RJ, Beerman LE, Vanderhoof JA. Increasing oral fluids in chronic constipation in children. Gastroenterology Nursing 1998; 21:156-61.

http://dx.doi.org/10.1111/j.1365277X.2011.0 $\underline{1179 . x}$

86. van Dijk M, Benninga MA, Grootenhuis MA, et al. Chronic childhood constipation: a review of the literature and the introduction of a protocolized behavioral intervention program. Patient Eduation and Counseling 2007; 67:63-77.

http://dx.doi.org/10.1016/j.pec.2007.02.002

87. Brazzelli M, Griffiths PV, Cody JD, et al. Behavioural and cognitive interventions with or without other treatments for the management of faecal incontinence in children. Cochrane Database of Systematic Reviews 2011; (12): CD002240.

88. Wessel S, Benninga MA. Diagnostic testing of defecation disorders. In: Nunez R, Fabbro A, Editors. Chronic constipation in children: diagnosis and treatment. New York: Nova Science Publishers Inc; 2013.p 185-98.

89. Borowitz SM, Cox DJ, Kovatchev B, et al. Treatment of childhood constipation by primary care physicians: efficacy and predictors of outcome. Pediatrics 2005; 115:873-7.

http://dx.doi.org/10.1542/peds.2004-0537

90. Guest JF, Candy DC, Clegg JP, et al. Clinical and economic impact of using macrogol 3350 plus electrolytes in an outpatient setting compared to enemas and suppositories and manual evacuation to treat paediatric faecal impaction based on actual clinical practice in England and Wales. Current Medical Research and Opinion 2007; 23:2213-25.

http://dx.doi.org/10.1185/030079907X210462

91. Youssef NN, Peters JM, Henderson W, et al. Dose response of PEG 3350 for the treatment of childhood fecal impaction. Journal of Pediatrics 2002; 141:410-4. http://dx.doi.org/10.1067/mpd.2002.126603 
92. Bekkali NL, van den Berg MM, Dijkgraaf $\mathrm{MG}$, et al. Rectal fecal impaction treatment in childhood constipation: enemas versus high doses oral PEG. Pediatrics 2009; 124:e11081115 . http://dx.doi.org/10.1542/peds.2009-0022

93. Perkin JM. Constipation in childhood: a controlled comparison between lactulose and standardized senna. Current Medical Research and Opinion 1977; 4:540-3. http://dx.doi.org/10.1185/03007997709115268

94. Lee-Robichaud H, Thomas K, Morgan J, et al. Lactulose versus Polyethylene Glycol for Chronic Constipation. Cochrane Database of Systematic Reviews 2010; (7): CD007570.

95. Berg I, Forsythe I, Holt P, et al. A controlled trial of 'Senokot' in faecal soiling treated by behavioural methods. Journal of Child Psychology and Psychiatry 1983; 24:543549.

http://dx.doi.org/10.1111/j.14697610.1983.tb $\underline{00131 . x}$

96. Bardisa-Ezcurra L, Ullman R, Gordon J. Guideline Development G. Diagnosis and management of idiopathic childhood constipation: summary of NICE guidance. British Medical Journal 2010; 340: c2585.10.1136/bmj.c2585. http://dx.doi.org/10.1136/bmj.c2585

97. Fandel T, Tanagho EA. Neuromodulation in voiding dysfunction: a historical overview of neurostimulation and its application. Urological Clinics of North America 2005; 32:1-10. http://dx.doi.org/10.1016/j.ucl.2004.09.006

98. Kamm MA, Dudding TC, Melenhorst J, et al. Sacral nerve stimulation for intractable constipation. Gut 2010; 59:333-40. http://dx.doi.org/10.1136/gut.2009.187989

99. van Wunnik BP, Peeters B, Govaert B, et al. Sacral neuromodulation therapy: a promising treatment for adolescents with refractory functional constipation. Dis Colon Rectum 2012; 55:278-85.

http://dx.doi.org/10.1097/DCR.0b013e31824 $\underline{05 \mathrm{c} 61}$

100. Clarke MC, Catto-Smith AG, King SK, et al. Transabdominal electrical stimulation increases colonic propagating pressure waves in paediatric slow transit constipation. Journal of Pediatric Surgery 2012; 47:227984.

http://dx.doi.org/10.1016/j.jpedsurg.2012.09. $\underline{021}$

101.Leong LC, Yik YI, Catto-Smith AG, et al. Long-term effects of transabdominal electrical stimulation in treating children with slow-transit constipation. Journal of Pediatric Surgery 2011; 46:2309-12. http://dx.doi.org/10.1016/j.jpedsurg.2011.09. $\underline{022}$

102.Garcia RC, Jimenez MA, Lorente AI. Surgical treatment for chronic constipation in children: Botox in chronic constipation. In: Nunez R, Fabbro A, Editors. Chronic constipation in children: diagnosis and treatment. New York: Nova Science Publishers Inc; 2013.p 321-45

103.Har AF, Rescorla FJ, Croffie JM. Quality of life in pediatric patients with unremitting constipation pre and post Malone Antegrade Continence Enema (MACE) procedure. Journal of Pediatric Surgery 2013; 48:173337.

104.Mugie SM, Machado RS, Mousa HM, et al. Ten-year experience using antegrade enemas in children. Journal of Pediatrics 2012; 161:700-4.

http://dx.doi.org/10.1016/j.jpeds.2012.04.042

105.Bonilla SF, Flores A, Jackson CC, et al. Management of paediatric patients with refractory constipation who fail caecostomy. Journal of Pediatric Surgery 2013; 48:19315.

http://dx.doi.org/10.1016/j.jpedsurg.2012.12. $\underline{034}$ 